\title{
PENGEMBANGAN DAN IMPLEMENTASI KURIKULUM ISMUBA DI SMP MUHMAMMADIYAH PAKEM SLEMAN YOGYAKARATA
}

\author{
Oleh. \\ Yogi Wibisono \\ Universitas Islam Negeri Sunan Kalijaga \\ e-mail: yogiwibisono@gmail.com
}

\begin{abstract}
This mini research discusses the development and implementation of ISMUBA Curriculum. Referring to the problems facing the world of education in the era of globalization and technology that have significant developments, the development and implementation of curriculum is important in education to create productive, efficient and creative learning processes. The purpose of this study is to determine teachers' understanding of ISMUBA curriculum in teaching and learning process. This research is a field research using a qualitative approach. Data collection techniques was conducdancted with interviews, observations, and documentation. Field data analysis was conducted by data reduction, organizing and processing in accordance with the research objectives. Based on the results of the study, the use of curriculum in Pakem Muhammadiyah Middle School does not use Islamic religious education curriculum, but instead uses ISMUBA curriculum, the Muhammadiyah Majelis education product. ISMUBA Curriculum Development is carried out in two ways, namely internal and external. The results of the field search analysis, development and implementation of the SMUBA curriculum can be said to be both good and complex. But teacher evaluation is needed to always innovate in the learning process.
\end{abstract}

Keywords: Development, Implementation, Curriculum

\begin{abstract}
Abstrak
Penelitian mini riset ini membahas tentang pengembangan dan implementasi kurikulum. Merujuk dari permasalahan yang dihadapai dunia pendidikan di era globalisasi dan tekhnologi yang signifikan perkembangannya, pengembangan dan pengimplementasian kurikulum penting dalam pendidikan untuk menciptakan proses pembelajaran yang produktif, efesien dan kratif. Tujuan dari penelitian ini untuk mengetahui pemahaman guru terhadap kurikulum ISMUBA dalam proses belajar mengajar. Penelitian ini adalah penelitian lapangan (field research) dengan menggunakan pendekatan kualitatif. Teknik pengumpulan data mengunakan wawancara, observasi, dan dokumentasi. Analisis data di lapangan dilakukan dengan reduksi data, pengorganisasian dan pengolahan data sesuai dengan tujuan penelitian. Berdasarkan hasil penelitian, penggunaan kurikulum di
\end{abstract}


SMP Muhammadiyah Pakem, tidak menggunakan kurikulum pendidikan agama Islam, melainkan menggunakan kurikulum ISMUBA, yaitu produk majelis Pendidikan Dasar dan Menengah Muhammadiyah. Pengembangan kurikulum ISMUBA dilaksanakan dalam dua sisi, yaitu intenal dan eksternal. Hasil analisis field research, pengembangan dan implementasi kurikulum ISMUBA bisa dikatakan baik dan kompleks. Tetapi diperlukan evaluasi guru untuk selalu berinovasi dalam proses pembelajaran.

Kata Kunci: pengembangan, Implementasi, Kurikulum

\section{A. PENDAhuluan}

Kurikulum merupakan salah satu komponen penting dalam pendidikan. Hal ini berkaitan dengan penentuan arah, isi dan proses pendidikan, yang pada akhirnya menentukan macam dan kualifikasi lulusan suatu lembaga pendidikan. Kurikulum juga disebut sebagai a plan of learning, yaitu rencana program pembelajaran, tanpa adanya kurikulum yang baik dan tetap maka akan sulit dalam mencapai tujuan dan sasaran pendidikan yang dicitacitakan. $^{1}$

Sebagai salah satu komponen penting, kurikulum dituntut untuk dapat mengikuti perkembangan dan tuntutan zaman. Hal ini menjadi salah satu faktor dalam pengembangan kurikulum yang kiranya perlu dilakukan untuk ketercapaian kompetensi peserta didik untuk dapat tetap survive di era milenial. Keberhasilan suatu bangsa dapat tercermin dari sistem pendidikannya, pendidikan memiliki peran penting untuk membantu manusia maupun sekelompok manusia dalam mengembangkan pandangan hidup

${ }^{1}$ Abdullah, Pengembangan Kurikulum Teori dan Praktik, (Jakarta:Gaya Media Pratama, 1999), hal. 3. (bagaimana manusia menjalani hidup dan kehidupannya), sikap hidup dan keterampilan hidup, yang dalam konteks pendidikan Islam harus bernafaskan ajaran Islam yang bersumber kepada Al-Qur'an dan Sunnah. ${ }^{2}$

Proses pendidikan Islam telah berlangsung sepanjang sejarah dan berkembang sejalan dengan perkembangan agama Islam dan sosial budaya dalam masyarakat. Peningkatan mutu pendidikan agama Islam bukanlah suatu usaha yang sederhana, sebab banyak aspek yang terkait dengan mutu pendidikan tersebut. $^{3}$ Berbagai cara dilakukan untuk meningkatkan mutu agama Islam, salah satunya melalui penataan kurikulum. Kualitas pembelajaran Pendidikan Agama Islam sangat dipengaruhi oleh bagaimana lembaga pendidikan dapat mengembangkan kurikulum yang sesuai dengan tuntutan masyarakat serta tujuan untuk menjadikan peserta didik sebagai penerus umat yang

2 Juwariyah, Kurikulum Ideal Antara Cita dan Realita, dalam Jurnal Pendidikan Agama Islam, Vol. 1, No. 2, 2004, hlm. 193.

3 Mahfud Junaidi Mansur, Rekonstruksi Sejaran Pendidikan Islam di Indonesia, (Jakarta: Departemen Agama RI, 2005), hal. 7. 
tangguh, kuat dan unggul dalam menjalani kehidupan yang akan datang.

Arah dan tujuan kurikulum pendidikan akan mengalami pergeseran dan perubahan seiring dengan dinamika perubahan sosial yang disebabkan oleh berbagai faktor, baik factor internal maupun faktor eksternal. Karena sifatnya yang dinamis dalam menyikapi perubahan, kurikulum mutlak harus fleksibel dan futuristik. Ketimpangan-ketimpangan dalam desain kurikulum karena kurang respon terhadap perubahan sosial boleh jadi berkonsekuensi kepada lahirnya output pendidikan yang "gagap" dalam beradaptasi dengan kondisi sosial yang dimaksud. $^{4}$

Atas dasar pertimbangan ini, maka pengembangan dan implementasi kurikulum menjadi salah satu aspek penting yang harus dilakukan dalam dunia pendidikan. Pengembangan kurikulum dilakukan oleh pihak sekolah sebagai langkah menjawab tantangan yang diberikan pada setiap zaman dan masyarakat. Hal ini pula yang dilakukan oleh SMP Muhammadiyah Pakem Yogyakarta yang juga melakukan pengembangan kurikulum pendidikan agama Islam. Oleh karena itu, hal tersebut menjadi dasar bagi penulis untuk melakukan mini riset tentang pengembangan dan implementasi kurikulum pendidikan agama Islam di SMP Muhammadiyah Pakem, Kab. Sleman, Yogyakarta. Berdasarkan uraian di atas, maka dapat diperoleh rumusan masalah yaitu Bagaimana pengembangan dan

4 Syamsul Bahri, Pengembangan Kurikulum Dasar dan Tujuannya, dalam Jurnal Ilmiah Islam Futura, Vol. XI, No. 1, Agustus 2011, hal. 16. implementasi kurikulum PAI di SMP Muhammadiyah Pakem, Kabupaten Sleman, Yogyakarta?

\section{B. METODE PENELITIAN}

Penelitian ini adalah penelitian lapangan (field research) dengan menggunakan pendekatan kualitatif. Pendekatan ini digunakan untuk mengkaji dan memperoleh makna secara mendalam tentang pengembangan dan implementasi kurikulum PAI di SMP Muhammadiyah Pakem, Kab. Sleman, Yogyakarta. Bogdan dan Taylor seperti dikutip Moleong mengatakan bahwa metodologi kualitatif merupakan prosedur penelitian yang menghasilkan data deskriptif berupa kata-kata tertulis maupun lisan dan orang-orang dan perilaku yang diamati. ${ }^{5}$ Ini jelas bahwa penelitian kualitatif merupakan penelitian yang mengungkapkan faktafakta yang terdapat di lapangan. Penelitian ini di laksanakan di SMP Muhammadiyah Pakem, Jl. Kaliurang Km 15, Tegalsari, Pakembinangun, Pakem, Sleman, Yogyakarta

Sumber data utama dalam penelitian kualitatif ialah kata-kata, dan tindakan, selebihnya adalah data tambahan seperti dokumen dan lainlain. ${ }^{6}$ Kata-kata dan tindakan orangorang yang diamati atau diwawancarai merupakan sumber data utama. Peneliti melihat potret empirik mengenai pengembangan dan implementasi kurikulum pendidikan agama Islam di SMP Muhammadiyah Pakem, Kab. Sleman, Yogyakarta.

5 Lexy. J. Moleong, Metodologi Penelitian Kualitatif, (Bandung: Remaja Rosdakarya, 2010), hal. 3.

${ }^{6}$ Ibid. hal. 157. 
Teknik pengumpulan data yang digunakan adalah wawancara, observasi, dan dokumentasi. Menurut Sugiyono, teknik pengumpulan data dengan observasi digunakan bila penelitian berkenaan dengan perilaku manusia, proses kerja, gejala-gejala alam dan bila responden diamati tidak terlalu besar. ${ }^{7}$ Analisis data di lapangan dilakukan dengan langkah-langkah, yaitu reduksi data, pengorganisasian dan pengolahan data sesuai dengan tujuan penelitian, dan penafsiran data sesuai dengan tujuan penelitian. Subjek penelitian adalah mereka yang dianggap dapat memberikan data dan informasi sesuai dengan fokus dan tujuan penelitian. Subjek dalam penelitian ialah guru PAI dan kepala sekolah.

\section{KERANGKA KONSEP}

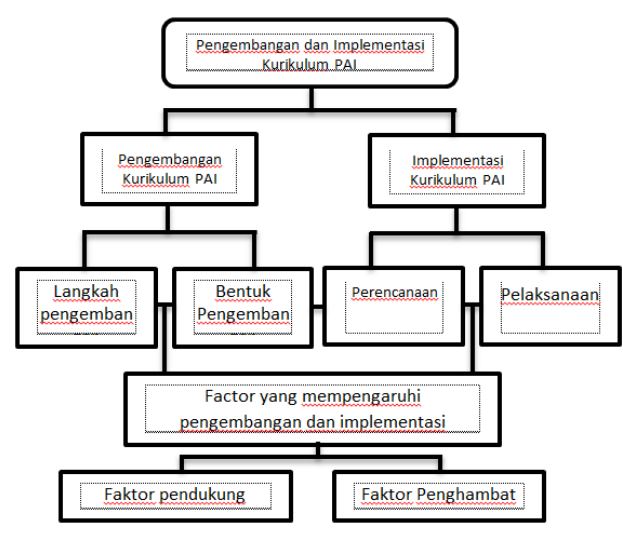

Gambar 1. Krangaka konsep pengembangan dan implemtasi kurikulum

\section{Pengembangan Kurikulum PAI}

Istilah kurikulum semula berasal dari istilah yang digunakan dalam dunia olah raga pada zaman Yunani

7 Sugiyono, Metode Penelitian Kuantitatif Kualitatif dan $R \& D$, (Bandung: Alfabeta, 2009), hal. 166.
Kuno. Secara etimologi, kurikulum berasal dari bahasa Yunani, yaitu dari kata curir yang berarti "pelari", dan curere yang artinya "tempat berpacu". Sehingga kurikulum diartikan sebagai jarak yang harus ditempuh oleh pelari. ${ }^{8}$ Sedangkan pengertian kurikulum secara terminologi adalah suatu program pendidikan yang berisikan berbagai bahan ajar dan pengalaman belajar yang diprogramkan, direncanakan dan dirancangkan secara sistemik atas dasar norma-norma yang berlaku yang dijadikan pedoman dalam proses pembelajaran bagi tenaga kependidikan dan peserta didik untuk mencapai tujuan pendidikan. ${ }^{9}$

Memandang kurikulum sebagai "all of the activities that are provided for student the school". Bahwasanya kurikulum tidak terbatas pada mata pelajaran saja, akan tetapi juga meliputi kegiatan-kegiatan lain, di dalam dan di luar kelas, yang berada di bawah tanggung jawab sekolah. ${ }^{10}$

Kurikulum merupakan konsep operasional suatu konsep pendidikan, maka makna kurikulum menjadi luas, seluas makna pendidikan itu. Dalam hal ini, kurikulum merupakan usaha menyeluruh dari suatu lembaga pendidikan untuk mewujudkan hasil yang diinginkan, baik dalam situasi

8 Tim Penyusun, Kamus Bahasa Indonesia, (Jakarta: Dinas Pendidikan Nasional, 1999), hal. 617.

Dakir, Perencanaan dan Pengembangan Kurikulum, (Jakarta: Rineka Cipta, 2010), hal. 3.

${ }^{10}$ S. Nasution, Asas-asas Kurikulum, (Jakarta: Bumi Aksara, 2001), hal. 5. 
sekolah maupun dalam situasi luar sekolah. ${ }^{11}$

Kurikulum dengan demikian
adalah seperangkat rencana
pembelajaran yang terdiri dari isi dan
materi-materi pelajaran yang
terstruktur, terprogram dan terencana dengan baik yang berkaitan dengan berbagai kegiatan dan interaksi sosial di lingkungan dalam menyelenggarakan kegiatan belajar mengajar dengan tujuan mencapai tujuan pendidikan. Dalam makna yang lebih luas, kurikulum adalah kumpulan seperangkat nilai yang dirancang untuk ditransformasikan kepada subjek didik, baik nilai-nilai dalam bentuk kognitif, afektif maupu psikomotor. dengan memperoleh seperangkat nilai tersebut, pola pikir dan perilaku subjek didik akan terbentuk sesuai dengan arah dan tujuan yang sudah diformulasikan sebelumnya, yaitu kurikulum. ${ }^{12}$

\section{Komponen-komponen Kurikulum}

Suatu kurikum harus memiliki kesesuaian atau relevansi. Kesesuaian ini meliputi dua hal. Pertama kesesuaian antara kurikulum dengan tuntutan, kebutuhan, kondisi dan perkembangan masyarakat. Kedua kesesuaian antar komponen-komponen kurikulum, yaitu sesuai dengan tujuan, proses sesuai dengan isi dan tujuan. Demikian juga evaluasi sesuai dengan proses, isi dan tujuan kurikulum. ${ }^{13}$

11 Munzir Hitami, Mengonsep Kembali Pendidikan Islam, (Pekanbaru: Infite Press, 2004), hal. 94.

12 Syamsul Bahri, "Pengembangan Kurikulum..., hal. 19

13 Lias Hasibuan, Kurikulum dan Pemikiran Pendidikan, (Jakarta: Gaungn Persada, 2010), hlm. 37
Pengembangan kurikulum PAI menurut setidaknya harus memperhatikan empat komponen, yaitu materi, tujuan, metode (strategi) dan evaluasi. Empat komponen tersebut menurut A. Rifqi Amin di dalamnya harus bermuatan nilai-nilai ajaran Islam pada setiap komponennya. Keempat komponen tersebut harus terjalin secara integral. ${ }^{14}$ Dilihat dari uraian struktural kurikulum ada 4 komponen utama, yakni tujuan, isi dan struktur kurikulum, strategi pelaksanaan, dan komponen evaluasi. Keempat komponen tersebut saling berkaitan satu sama lain sehingga merefleksikan satu kesatuan yang utuh sebagai program pendidikan. ${ }^{15}$

a. Tujuan Kurikulum

Terkait dengan tujuan kurikulum tersebut, David Pratt mengemukakan enam kriteria yang harus dipenuhi dalam menetapkan tujuan kurikulum, antara lain: mempunyai tujuan yang jelas, mengidentifikasi terhadap perubahan-perubahan yang dibutuhkan oleh pengajar, ringkas dan jelas, tepat sasaran, menyeluruh, serta dapat diterima.

b. Isi dan Struktur Kurikulum

Isi kurikulum atau bahan pelajaran bertalian erat dengan tujuan pendidikan. Oleh karena itu, dalam menentukan isi kurikulum hendaknya memperhatikan akan tujuan akhir pendidikan. Para pengembang kurikulum harus mengerti dan

14 A. Rifqi Amin. Sistem Pembelajaran pendidikan Agama Islam Pada Perguruan Tinggi Umum, (Yogyakarta: Deepublish, 2014), hal. 46.

15 Syafruddin Nurdin, Guru Profesional dan Implementasi Kurikulum, (Jakarta: Ciputat Press, 2002), hal. 51. 
memahami benar-benar akan masingmasing tujuan pendidikan. Sehingga dalam menyusun isi kurikulum tidak bertentangan dengan tujuan pendidikan. Karena isi kurikulum merupakan jalan untuk mencapai tujuan pendidikan. ${ }^{16}$

Ada beberapa kriteria yang dapat membantu para perancang kurikulum dalam menentukan isi kurikulum, yaitu: isi kurikulum harus sesuai, tepat dan bermakna bagi perkembangan siswa; isi kurikulum harus mencerminkan kenyataan sosial, artinya harus sesuai dengan tuntutan hidup nyata dalam masyarakat; isi kurikulum harus mengandung pengetahuan ilmiah yang komprehensif, artinya mengandung aspek intelektual, moral, sosial secara seimbang, isi kurikulum harus mengandung aspek ilmiah yang tahan uji, isi kurikulum harus mengandung bahan yang jelas, teori, prinsip, konsep yang terdapat di dalamnya bukan sekadar informasi faktual; isi kurikulum harus dapat menunjang tercapainya tujuan pendidikan. ${ }^{17}$

c. Strategi Pelaksanaan Kurikulum Strategi pelaksanaan kurikulum memberi petunjuk bagaimana kurikulum tersebut dilaksanakan di sekolah. Kurikulum dalam pengertian program pendidikan masih dalam taraf harapan atau rencana yang harus diwujudkan secara nyata di sekolah sehingga dapat mempengaruhi dan mengantarkan anak didik kepada tujuan pendidikan. Oleh karena itu

16 Achmad Sudja'i, Pengembangan Kurikulum, (Semarang: Akfi Media, 2013), hal. 54.

17 Syafruddin Nurdin, Guru Profesional..., hal. 55-56. komponen strategi pelaksanaan kurikulum memegang peranan penting dalam pencapaian tujuan pendidikan tersebut.

Berhasil atau tidaknya kurikulum pendidikan yang telah direncanakan atau ditetapkan, kuncinya adalah terletak pada proses belajar mengajar sebagai ujung tombak dalam mencapai tujuan pembelajaran. Oleh karena itu proses belajar mengajar yang terencana, terpola dan terprogram secara baik dan sesuai dengan kebutuhan peserta didik. Penyusunan pengajaran (RPP) sangat penting dalam pelaksanaan pembelajaran dan RPP merupakan ciri dan indikasi keberhasilan pelaksana kurikulum. Oleh sebab itu kuncinya adalah guru harus menguasai dan memiliki kemampuan dalam penyusunan RPP, materi pelajaran, desain pengajaran, pengelolaan kelas, dan penilaian hasil belajar (evaluasi).

Di samping penguasaan dalam bidang lain-lainnya sebagaimana tertuang dalam 10 kompetensi guru yang harus dikuasai dan dimiliki, yaitu: menguasai bahan, mengelola program belajar mengajar, melaksanakan program belajar mengajar, mengenal kemampuan anak didik, menguasai landasan-landasan kependidikan, mengelola interaksi belajar mengajar, mengenal fungsi, program bimbingan, penyuluhan di sekolah, menilai prestasi untuk kepentingan pengajaran, mengenal dan menyelenggarakan administrasi sekolah, memahami prinsip serta menafsirkan hasil 
penelitian pendidikan guna keperluan pengajaran. ${ }^{18}$

d. Evaluasi Kurikulum

Evaluasi kurikulum adalah suatu tindakan pengendalian, penjaminan dan penetapan mutu kurikulum, berdasarkan pertimbangan dan kriteria tertentu, sebagai bentuk akuntabilitas pengembang kurikulum dalam rangka menentukan keefektifan kurikulum. ${ }^{19}$ Dalam pengembangan kurikulum, evaluasi merupakan salah satu komponen penting dan tahap yang harus ditempuh oleh guru untuk mengetahui keefektifan kurikulum. Hasil yang diperoleh dapat dijadikan balikan (feed-back) bagi guru dalam memperbaiki dan menyempurnakan kurikulum. ${ }^{20}$

\section{PEMBAHASAN}

\section{Deskripsi Hasil Mini Riset}

Berdasarkan hasil mini riset yang telah dilakukan tentang pengembangan dan implementasi kurikulum pendidikan agama Islam di SMP Muhammadiyah Pakem, Kab. Sleman, Yogyakarta dapat dideskripsikan sebagai berikut:

a. Pengembangan Kurikulum PAI di SMP Muhammadiyah Pakem Pengembangan kurikulum PAI di sekolah, dilaksanakan dalam dua segi, yaitu pengembangan didalam kelas (intenal) dan diluar kelas (eksternal). Pengembangan didalam kelas dilaksanakan oleh guru PAI, Sekolah SMP muhammadiyah menggunakan pendidikan ISMUBA (Al-Islam,

\begin{tabular}{l}
\hline $18 \quad$ Syafruddin Nurdin, Guru \\
Profesional..., hal. 56-58. \\
${ }^{19}$ Zainal Arifin, Konsep dan Model \\
Pengembangan..., hal. 266. \\
${ }^{20}$ Ibid., hal. 263.
\end{tabular}

KeMuhammadiyahan dan Bahasa Arab) dan system pembelajarannya sesuai standarisasi pendidikan Muhammadiyah. Pendidikan ISMUBA merupakan ciri khas dan keunggulan sekolah Muhammadiyah.

Pengembangan kurikulum

ISMUBA dilakukan oleh guru yang berkompeten, dengan mengembangkan proses belajar mengajar yang meliputi strategi pembelajaran, metode, dan media pembelajaran yang sudah dirancang pada silabus dan RPP. Didalam materi ISMBU ada Al Islam, KMD (Kemuhammadiyahan) dan Bahasa Arab, mata pelajaran Al Islam terdiri dari, Al-Qur'an dan hadis, Aqidah Akhlak, Ibadah (fiqih), dan Tarih/Sejarah Islam.

Dalam hal ini, guru ISMUBA diharapkan dapat mengembangkan metode pembelajaran dengan mengkontekstualisasikan materi pembelajaran. Sedangkan dalam media pembelajaran, guru ISMUBA mengaku lebih variatif dalam penggunaan media untuk mendukung proses pembelajaran.

Dalam pembelajaran ISMUBA, guru juga menanamkan Ideologi keMuhammadiyahan dengan menilik sejarah dan para tokoh Muhammadiyah. Dengan demikian, peserta didik dapat termotivasi untuk dapat berkarya nyata seperti memajukan keorganisasiannya, serta melestrarikan nilai-nilai Muhammadiyah.

Sementara itu, dalam pengembangan kurikulum ISMUBA di luar kelas dikembangkan dengan menciptakan suasana religius untuk lebih memaksimalkan proses 
internalisasi nilai-nilai karakter dan agama kepada peserta didik. Beberapa kegiatan diciptakan di luar kurikulum tertulis untuk mendukung keberhasilan pendidikan ISMUBA, seperti: membaca ayat suci al Quran sebelum proses belajaran mengajar, menghafalkan al Quran, shalat dhuha bersama, tausiyah rutin setiap bulan yang diadakan diluar sekolahan dan kegiatan lainnya yang menunjang pendidikan ISMUBA.

b. Implementasi ISMUBA di

Kurikulum Muhammadiyah Pakem.

Dalam mengimplementasikan kurikulum ISMUBA di SMP Muhammadiyah Pakem, guru ISMUBA telah memahami isi dalam kurikulum tersebut. Hal ini terlihat dari proses pembelajaran dikelas yang menyesuaikan dengan kurikulum ISMUBA. Tetapi, pada proses pembelajarannya masih ada beberapa guru yang tidak menerapkannya. Untuk kelas IX, guru ISMUBA masih mengunakan kurikulum KTSP 2006. Dikarenakan, dalam penerapannya kurikulum ISMUBA disekolah melalui system bertahap. sedangkan kurikulum sekolah secara umum telah menggunakan kurikulum 2013.

Menurut bapak Hendro Sucipto, selaku kepala sekolah SMP Muhammadiyah Pakem, menerapkan kurikulum yang telah ditetapkan oleh Dinas Pendidikan dan Majlis Pendidikan Dasar dan Menengah Muhammadiyah dan bertujuan akan memberikan wawasan ilmu yang terpadu dan berimbang. Ditambah dengan berbagai kegiatan yang menunjang daya olah raga, olah pikir dan olah jiwa, diharapkan para peserta didik mampu mengembangkan dirinya sebagai "Insan Kammil". ${ }^{21}$

Kurikulum ISMUBA hanya dipergunakan untuk pendidikan agama Islam (Al-Islam), khususnya di sekolah Muhammadiyah. Kurikulum ini, tidak dipergunakan untuk mata pelajaran umum. Oleh karena itu, diharapkan pada guru ISMUBA untuk dapat mengaplikasikan kedalam proses belajar mengajar dikelas. Tetapi, dalam lapangannya atau realitanya masih ada guru yang tidak menerapakan atau mengaplikasikan kurikulum tersebut. Salah satunya guru masih menggunakan kurikulum KTSP. Karena dari segi teknis, kurikulum KTSP lebih mudah diaplikasikan dalam pembelajaran.

Ada beberapa masalah yang terjadi pada pembelajaran ISMUBA, seperti yang dikatakan oleh bapak Irfandi Rahman, bahwasanya guru ISMUBA disini sekolahan ini masuk kurang dalam pengadaan tenaga pendidik, guru ISMUBA yang dimiliki pihak sekolah saat ini hanya 5 guru saja termasuk kepala sekolah didalamnya dan guru ISMBU sendiri bisa menggampu 3 (tiga) mata pelajaran sekaligus. $^{22}$

Oleh karenan itu, pihak sekolah seharusnya segera mencari dan mengadakan guru ISMUBA agar dapat mencukupi dari kekurangan tersebut, Padahal dalam prosedurnya, setiap guru ISMUBA hanya menggampu 1

${ }^{21}$ Wawancara, Kepala Sekolah Bapak Hendro Sucipto, Kamis, 03, Mei 2018, pukul, 10.30

${ }^{22}$ Wawancara, Guru ISMUBA, Bapak Irfandi Rahman, jum'at, 04, Mei 2018, pukul 12.45 
(satu) mata pelajaran tidak boleh lebih.

Karena dapat mempengaruhi terhadap pengelolaan pembelajaran dikelas, keefektivitas pembelajaran berkurang, dan pembelajaran menjadi tidak efesien. demikian akan berimbas pada perkembangan intelektual peserta didik dalam memahami materi al-Islam.

Proses pembelajaran ISMUBA yang dilakukan oleh guru ISMUBA menggunakan metode yang bervariasi, seperti ceramah, diskusi, dan kelompok. Meski begitu, dalam pengembangnya juga harus menyesuaikan kondisi dan situasi dikelas. Dalam pembelajaran ISMUBA yang disampaikannya sebisa mungkin guru mengkontekstualisasikan dalam kehidupan sekarang atau keadaan yang terjadi saat ini. Hal ini, dilakukan untuk mengingat semakin kompleksnya dinamika kehidupan, dan hal itu sangat dibutuhkan oleh siswa agar mereka dapat bertahan dan siap memghadapi tantangan dan perubahan zaman.

Sementara, terkait kesiapan perangkat pembelajaran, guru ISMUBA secara rutin mempersiapkan Rencana Pelaksanaan Pembelajaran (RPP) maupun silabus. Meski begitu, dalam pengaplikasiannya ada juga beberapa guru yang tidak menggunakan RPP dalam pelaksanaan pembelajaran dikelas, karena menyesuaikan kondisi dan situasi dikelas, dengan alasan agar penyampaian materi pelajaran dapat dipahami oleh peserta didik dan tidak terbuang sia-sia apa yang disampaikan.

Tahap akhir dari implementasi kurikulum ISMUBA/PAI di SMP Muhammadiyah adalah evaluasi pembelajaran. Evaluasi dilaksanakan sesuai dengan kebijakan sekolah, yaitu meliputi ulangan harian, ujian tengah semester, ujian praktek, ujian akhir semester, tugas dan lain sebagainya. Hal ini dilakukan untuk menilai ketiga aspek yang masuk dalam penilaian, yaitu aspek kognitif, afektif dan psikomotorik. Sementara itu, faktor yang dapat mempengaruhi implementasi kurikulum ISMUBA di SMP Muahmmadiyah Pakem, yaitu: 1) faktor pendukung, seperti siswa yang responsif, dukungan melalui religius culture di sekolah, dan optimalisasi melalui mata pelajaran Pendidikan ISMUBA. Kedua, faktor penghambat, seperti sarana dan prasarana, terbatasnya guru ISMUBA di sekolah, serta peran orang tua yang masih minim untuk mendukung programprogram sekolah.

\section{Analisis Pengembangan dan Implementasi Kurikulum ISMUBA di SMP Muhammadiyah Pakem Sleman, Yogyakarta}

Pengembangan kurikulum di SMP Muhammadiyah Pakem tidak menggunakan kurikulum pendidikan agama Islam, melainkan menggunkan kurikulum ISMUB, yang sudah menjadi keunggulan dan cri khas lembaga pendidikan Muhammadiyah. Menurut Tasman Hamimi, ISMUBA merupakan ciri khas sekolah Muhammadiyah sebagai sebuah keseimbangan intelektual dan keagamaan, harus terus ditanamkan dalam proses belajar mengajar. Pendidikan ISMUBA memiliki motivasi dan tujuan untuk menumbuh kembangkan aqidah melalui pengalaman dan pembiasaan tentang 
Al-Islam, mewujudkan manusia Indonesia yang taat beragama dan berakhlaqul karimah, yakni manusia yang berpengetahuan, rajin beribadah, cerdas, jujur, disiplin, serta mengembangkan budaya Islami dalam komunitas sekolah sesuai Al-Quran dan As-sunnah. ${ }^{23}$

ISMUBA adalah mata pelajaran yang sangat penting, karena menjadi ciri khas yang membedakan sekolah lainnya dengan sekolah Muhammadiyah. ${ }^{24}$ Bahwasannya materi ISMUBA sekolah Muhammadiyah tak jauh beda dengan apa yang diterapkan disekolah pada umumnya. Perbeda yang menyolok dalam materi ISMUBA dan materi PAI disekolah umum ialah isi kurikulum dan buku ajar yang dijadikan pegangan guru dalam mengajar, buku ajar pada materi ISMUBA disusun oleh Majlis Pendidikan Muhammadiyah bukan dari pemerintah pusat, sedangankan yang dipakai oleh sekolah umum mengunakan buku yang sudah ditentukan dari pusat/pemerintah. Pembelajaran ISMUBA diharapkan mampu mewujudkan tujuan dari kurikulim ISMUBA dan tetep menjadi keunggulan sekolah Muhammadiyah. Pengembangan kurikulum ISMUBA di dalam kelas yang dilakukan oleh beberapa guru ISMUBA dirasa masih kurang maksimal mengingat tidak disiapkannya secara rutin perangkat pembelajaran. Padahal kompetensi ini

${ }^{23}$ Mulyono, Implementasi Pendidikan Karakter dalam Mata Pelajaran ISMUBA, Mudarisa: Jurnal Kajian Pendidikan Islam, Vol. 6, No. 1, Juni 2014, hlm. 114-140

${ }^{24}$ Suliswiyadi, Pembelajaran Al-Islam Reflektif, (UMMgl Press: Gramasurya, 2013), hlm. 72 sangat diperlukan untuk keberhasilan pembelajaran nantinya.

Peraturan Pemerintah No. 19 tahun 2005 tentang Standar Nasional Pendidikan, guru di Indonesia diharapkan punya empat kompetensi dalam menjalankan profesinya. Kompetensi tersebut adalah kompetensi pedagogik, kepribadian, profesional, dan kompetensi sosial. ${ }^{25}$ Majelis Pendidikan Dasar dan Menengah Pimpinan Pusat Muhammadiyah juga, telah memiliki standarisasi atau syarat dalam menentukan guru ISMUBA. Sesuai dengan lampiran surat keputusan Majelis Pendidikan Dasar dan Menengah Pimpinan Pusat Muhmmadiyah, Bab V Tentang Standar Guru Pendidikan ISMUBA. ${ }^{26}$

Kenyataan di lapangan banyak guru yang belum memenuhi kriteria kompetensi tersebut. Untuk itu guru harus banyak belajar dan berlatih karena pada dasarnya tidak ada guru yang tak bisa mengajar. ${ }^{27}$ Maka, untuk mengatasi hal tersebut, seperti telah disinggung sedikit di atas, pihak sekolah harus segera mencari tambahan guru, untuk mencukupi kapasitas yang diperlukan pada pendidikan ISMUBA dan guru juga ikut berpartisipasi untuk

25 Peraturan Pemerintah Republik Indonesia, Nomer. 19, Tentang Standar Nasional Pendidikan, BAB VI, Pasal 28, tahuan 2005,

${ }^{26}$ Lampiran Surat Keputusan Majelis Pendidikan Dasar dan Menengah Pimpinan Pusat Muhammadiyah, Tentang Standar Guru ISMUBA, BAB V, No. 98/KEP/l.4/F/2017.

27 Radiatan Mardiah dkk., Pengembangan Perangkat Pembelajaran untuk Peningkatan Kompetensi Ujian Nasional di Kabupaten Muaro Jambi, Tanjung Jabung Barat dan Tanjung Jabung Timur Provinsi Jambi, Jurnal Pengabdian pada Masyarakat No. 55 Tahun 2013, hal. 16. 
mengikuti pelatihan bagi guru yang belum pengalaman di bidang studinya. Dengan meningkatnya kualitas guru, diharapkan kualitas output sekolah pun dapat menjadi lebih baik dan sesuai dengan tujuan sekolah dan organisasi Muhammadiyah.

Pengembangan

kurikulum

disekolah masih perlu dilakukan pembenahan terutama pengembangan yang dilakukan oleh guru mata pelajaran ISMUBA. Guru ISMUBA dalam melaksanakan tugasnya dirasa perlu untuk lebih inovatif dalam setiap proses pembelajaran, sehingga bukan metode itu-itu saja (monoton) yang banyak diterapkan. Terutama bagi guru baru atau kurangnya pengalaman dalam mengajar, oleh karena itu, kepala sekolah/pihak sekolah dirasa perlu untuk selalu membimbing dan memberi arahan dan mengirim setiap ada pelatihan guru.

Sementara, pengembangan kurikulum pendidikan agama Islam yang dilakukan di luar kelas, boleh dikatakan cukup baik dalam menciptakan suasana religius. Menurut Asmaun Sahlan, bahwa salah satu upaya yang dapat dijadikan alternatif pendukung akan keberhasilan pendidikan agama Islam khususnya ${ }^{28}$ Dengan ini, dapat menciptakan budaya religius (religious culture) di sekolah sebagai bentuk pengembangan Pendidikan ISMUBA dalam berbagai bentuk kegiatan, misalnya ekstra kurikuler seperti Tapak Suci, Ikatan

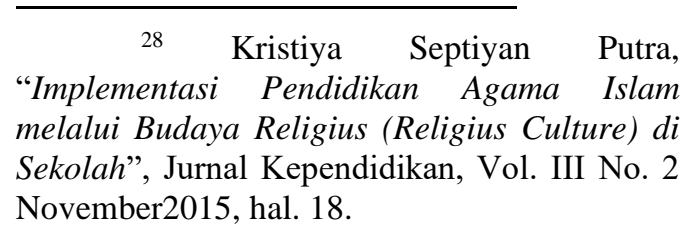

Pelajar Muhammadiyah (IPM), Hizbul Wathn (HW) yang satu sama lainnya saling terintegrasi oleh pendidikan dan social masyarakat (sociality humanism).

Selain itu, adanya mata pelajaran Pendidikan Ke-Muhammadiyahan juga turut adil dalam internalisasi nilia-nilai keagamaan pada diri peserta didik. Hal ini secara tidak langsung dapat mempengaruhi terhadap keberhasilan pengembangan intelktual peserta didik. Selain itu, pendidikan ISMUBA memberikan kekhasan dan keunggulan pada sekolah Muhammadiyah yang memiliki keunikan dan keunggulan didalamnya. Mata pelajaran Pendidikan ISMUBA juga menanamankan ideologi ke-Kemuhammadiyahan pada peserta didik, bertujuan untuk membentuk kader-kader yang memiliki keunggulan dalam IPTEK dan IMTAQnya. Sesuai dengan perkataan K.H Ahmad Dahlan yaitu,

"Hidup-Hidupilah

Muhammadiyah dan jangan engkau mencari hidup di Muhammadiyah".

Mata pelajaran ISMUBA juga diampu oleh guru ISMUBA yang memiliki pengalaman didalamnya. Hal ini sangat penting untuk dilakukan mengingat semakin kompleksnya dinamika kehidupan, dan peserta didik perlu untuk memiliki sebuah pegangan supaya tidak mudah goyah, yaitu akidah serta akhlak yang karimah.

Penciptaan nilai religius dan kebudayaan disekolah ini harus didukung oleh seluruh warga sekolah dan stakeholder sekolah. Pendidikan Muhammadiyah mempunyai pendidikan yang berelevensi dengan lingkungan kehidupan, yang melahirkan prinsip amaliah, amal 
ilmiah. ${ }^{29}$ jadi ilmu akan bermanfaatkan ketika diamalkan untuk kepentingan masyarakat banyak. Namun terlepas dari hal itu, untuk mewujudkannya harus diimbangi dengan partisipasi aktif orang tua sebagai respon dari hasil belajar peserta didik. Dalam pengembangkan kurikulim dibagi, menjadi dua partisipasi masyarakat, yaitu partisipasi kuantitatif dan partisipasi kualitatif. Partisipasi kuantitatif menunjuk pada frekuensi keikutsertaan orang tua dan masyarakat terhadap pengembangan dan pelaksanaan kurikulum. Sementara partisipasi kualitatif menunjuk pada tingkat dan derajatnya. Oleh karena itu, sekolah seharusnya menjadi patner orang tua dan masyarakat. ${ }^{30}$

\section{E. KESIMPULAN}

Kurikulum yang digunakan SMP Muhammadiyah Pakem ialah Kurikulum ISMUBA bukan kurikulum PAI. Pengembangan yang dilakukan di SMP Muhammadiyah Pakem dilakukan dalam dua aspek, yaitu pengembangan di dalam kelas dan pengembangan di luar kelas. Pengembangan kurikulum di dalam kelas dilakukan oleh guru ISMUBA dengan mengembangkan proses belajar mengajar yang meliputi strategi pembelajaran, metode, dan media pembelajaran. Sementara itu, pengembangan kurikulum ISMUBA di

\footnotetext{
${ }^{29}$ Fandi Ahmad, Pemikirian K.H Ahmad Dahlan Tentang Pendidikan dan Implementasinya di SMP Muhammadiyah 6 Yogyakarta,Profetika, Jurnal: Studi Islam, Vol. 16, No. 02, Desember, 2015, hlm. 151

${ }^{30}$ Muhammad Nasir, "Pengembangan Kurikulum Berbasis Madrasah", Jurnal Hunafa, Vol. 6, No.3, Desember 2009, hal. 295.
}

luar kelas dikembangkan dengan menciptakan suasana religius untuk lebih memaksimalkan proses internalisasi nilai-nilai karakter dan agama kepada peserta didik.

Implementasi kurikulum ISMUBA di SMP Muhammadiyah Pakem, salah satu guru masih menggunakan kurikulum KTSP 2006 meski kurikulum sekolah secara umum menggunakan kurikulum 2013. Dalam implementasi di kelas, guru PAI tidak begitu maksimal menyiapkan perangkat pembelajaran. Akan tetapi hal tersebut dapat diatasi dengan tetap profesionalnya guru dalam mengajar.

Kurikulum ISMUBA di SMP Muhammadiyah Pakem mengarah pada ilmu agama yang berintegrasi dengan ilmu pengetahuan (sains). Dalam pembelajaran ISMUBA guru juga tak luput untuk menanamkan ideologi keMuhammadiyahan kepada peserta didik terlepas dari mata pelajaran $\mathrm{Ke}$ Muhammadiyahan (KMD). Hal ini dilakukan untuk mengingt ciri khasan dan keunggulan dari sekolah SMP Muhammadiyah, yang merupakan sekolah di bawah naungan Majlis Pendidikan Muhammadiyah.

\section{DAFTAR PUSTAKA}

Abdullah. Pengembangan Kurikulum Teori dan Praktik. Jakarta: Gaya Media Pratama, 1999.

Amin. A. Rifqi. Sistem Pembelajaran pendidikan Agama Islam Pada Perguruan Tinggi Umum. Yogyakarta: Deepublish, 2014.

Bahri, Syamsul. "Pengembangan Kurikulum Dasar dan Tujuannya", dalam Jurnal Ilmiah 
Islam Futura, Vol. XI, No. 1, Moleong, Lexy. J. Metodologi Agustus 2011.

Dakir. Perencanaan dan Penelitian Kualitatif. Bandung: Pengembangan Kurikulum Rosdakarya, 2010.

Jakarta: Rineka Cipta, 2010.

Fandi Ahmad, Pemikirian K.H Ahmad

Dahlan Tentang Pendidikan dan

Implementasinya di SMP

Muhammadiyah

Yogyakarta,Profetika, Jurnal:

Studi Islam, Vol. 16, No. 02, Desember, 2015.

Hitami, Munzir. Mengonsep Kembali

Pendidikan Islam. Pekanbaru: Infite Press, 2004.

Juwariyah. "Kurikulum Ideal Antara

Cita dan Realita", dalam Jurnal

Pendidikan Agama Islam, Vol. 1, No. 2, 2004.

Lampiran Surat Keputusan Majelis

Pendidikan Dasar dan Menengah Pimpinan Pusat Muhammadiyah, Tentang Standar Guru ISMUBA, BAB V, No. 98/KEP/1.4/F/2017.

Mansur, Mahfud Junaidi. Rekonstruksi

Sejaran Pendidikan Islam di

Indonesia. Jakarta: Departemen

Agama RI, 2005.

Mardiah, Radiatan dkk.,

"Pengembangan Perangkat

Pembelajaran untuk Peningkatan

Kompetensi Ujian Nasional di

Kabupaten Muaro Jambi,

Tanjung Jabung Barat dan

Tanjung Jabung Timur Provinsi Jambi”, Jurnal Pengabdian pada

Masyarakat No. 55 Tahun 2013.

Mulyono, Implementasi Pendidikan

Karakter dalam Mata Pelajaran

ISMUBA, Mudarisa: Jurnal

Kajian Pendidikan Islam, Vol. 6, No. 1, Juni 2014. 